\title{
The Major Ideologies of Liberalism, Socialism and Conservatism
}

\author{
James Alexander \\ Bilkent University
}

In the last thirty years ideologies have been treated as if they are contingent assemblages of concepts. This has complicated the study of ideologies so much that some philosophical consideration now seems necessary. In this article an original theory is put forward in which the three major ideologies of liberalism, socialism and conservatism are understood to be three differing views about the nature of the fundamental criterion by which politics should be judged. Since this theory explains the relation between the three as if they are elaborations of the same original criterion, it enables us to see how the ideologies relate to and yet differ from each other.

Keywords: ideologies; definition; liberalism; socialism; conservatism

We are often told that we should take ideologies more seriously in political science and political philosophy (Cohen, 2008, p. 1; Freeden, 1996, p. 132; Knight, 2006; Vincent, 2004, p. 73.) The problem is, of course, that ideologies tend to push argument in an ad hominem direction, which is perhaps why academic writers tend to write about their practices and theories as if they can be considered separately from ideologies. The consequence of this until now has been that the study of ideologies has become what it should not have become: a coterie activity.

The standard view of ideologies - the one taken, for instance, by the Journal of Political Ideologies and the recent Oxford Handbook of Political Ideologies - is one dominated by collection. This point of view is necessary, but an emphasis on it has made the study of ideologies in the last thirty or so years excessively ad hoc. In this article I therefore offer a theory of the three major ideologies in terms not of collection, but of division. Plato in Phaedrus (265c-e) wrote that whenever we think about something we must engage in both synagoge and diairesis - 'collection' and 'division'. 'Collection is evidently to consist in bringing together specific Ideas under a common generic Idea, division is the hierarchical arrangement under that generic Idea of all its constituent sub-genera and species' (Raven, 1965, p. 226). Recent scholars have tended to study ideologies in terms of collection. ${ }^{1}$ Consequently, the more purely philosophical task of division - the imposition of categories, the questioning of assumptions, so that the subject matter can be brought into some sort of order - is neglected. The classic books on ideologies are often divided into chapters entitled 'Liberalism', 'Socialism', 'Conservatism' and so on, but there is no explanation why.

The argument of this article is that although it is necessary to acknowledge the force of the contemporary scholarly claim that ideologies are 'variegated', 'overlapping', 'intermixed', 'complex', 'plural' and so on, it is also necessary to observe that there are some principles or concepts or criteria in them which are so fundamental they deserve to be characterised. I shall argue that it is possible to explain why liberalism, socialism and 
conservatism are considered the three major ideologies. I shall first discuss some of the problems of the standard definition of the word 'ideology' in order to suggest a revision of it, before going on to characterise each of the three major ideologies, using enough representative quotation and argument to justify the claim that they are ideally distinct in a way that is philosophically possible to capture, also to justify the claim that all the complications evident to the scholars who have collected ideologies follow from the fact that the ideologies are distinct in how they characterise what is nonetheless the same criterion about what is of value in politics.

\section{Ideology}

It is useful to begin with a fairly standard definition of ideology.

An ideology is a set of ideas by which men posit, explain and justify the ends and means of organized social action, irrespective of whether such action aims to preserve, amend, uproot or rebuild a given social order (Seliger, 1976, p. 14).

This is the definition found in what are now the classic works on ideologies in English by Andrew Heywood, Andrew Vincent and Michael Freeden. ${ }^{2}$ All of these books are constructed in the same manner. They lay down a definition of ideology in the singular before going on to characterise a set of ideologies in the plural. Ideology is defined; the separate ideologies are not. Ideologies are 'complex' (Freeden, 1996, p. 13; Heywood, 1998, pp. 17-9; Vincent, 1992, p. 18). They are not 'hermetically sealed systems of thought' (Heywood, 1998, p. 13). They are 'modular structures, frequently exhibiting a highly fluid morphology (Freeden, 1996, p. 88). They are 'internally complex, intermixed and overlapping' (Vincent, 1992, p. 19). Therefore, 'to compartmentalize ideologies into prefabricated categories called socialism or liberalism is to fly in the face of the evidence' (Freeden, 1996, pp. 87-8). ${ }^{3}$ Yet in all of these books the ideologies are compartmentalised into prefabricated categories called chapters.

Each of the three classic studies places the first three ideologies chapter by chapter in the same exact order ('Liberalism', 'Conservatism', 'Socialism') with the remaining ideologies ('Nationalism', 'Environmentalism', 'Feminism' and so on) in no apparent order.' Liberalism, conservatism and socialism are the 'major ideologies', and liberalism is the most important or the original of the three. ${ }^{5}$ Yet there is no explanation of why the ideologies are divided this way. Theory has only gone as far as collection, and not as far as division. Freeden has done most to justify the standard method of collection. He declares that ideologies are 'combinations of political concepts' (Freeden, 1996, p. 140). Some concepts are 'core', some are 'adjacent', and some are 'peripheral'. He explains this using a metaphor.

Ideologies may be likened to rooms that contain various units of furniture. ... If we [enter a room and] find liberty, rationality, and individualism at its centre, while equality - though in evidence - decorates the wall, we are looking at an exemplar of liberalism. If order, authority, and tradition catch our eye upon opening the door, while equality is shoved under the bed or, at best, one of its weaker specimens is displayed only when the guests arrive, we are looking at a version of conservatism. Core, adjacent and peripheral units pattern the room and permit its categorization (Freeden, 1996, pp. 86-7). 
This ideological home exhibition enables each ideology to be loosely characterised. ${ }^{6}$ The ideologies share many core, adjacent and peripheral concepts, but they arrange and order them in different ways. This 'morphological' theory is so effective in justifying collection that there is evidence that Heywood and Vincent in their second editions were greatly influenced by it. Each writer collects in his chapters a set of core, adjacent and peripheral concepts, and then goes on to discuss the different manifestations of each ideology, running through some famous theories and some incidents from party history, always indicating that each ideology contains multitudes: that, for instance, socialism contains utopian socialism, ethical socialism, Marxism, Christian socialism, Fabian socialism and so on. But these accounts achieve historical plausibility in collecting instances of the various ideologies at a cost. They cannot explain why the ideologies are divided into liberalism, socialism, conservatism and so on. So they fall back on common sense and observe simply that they are divided in this way. This is inadequate.

Part of the problem is that the standard definition of ideology in the singular is too simple. An ideology is surely not just, as the standard definition has it, 'a set of ideas by which men posit, explain and justify the ends and means of organized social action, irrespective of whether such action aims to preserve, amend, uproot or rebuild a given social order'. It is a distinctively modern set of ideas. Our authors of course recognise that 'the age of ideologies can be said to date from 1789' (Heywood, 1998, p. 22; compare Vincent, 1992, p. 1 and Freeden, 1996, p. 92), but they perhaps place insufficient emphasis on the fact that 'the concept of ideology was only possible as part of a modernist perspective that envisaged wholesale change as possible' (Schwarzmantel, 1998, p. 63). Ideologies only emerged when the traditional order was put to the question in the abstract by enlightenment and in the concrete by revolution. All ideologies are après la déluge. They are a response to the imagined possibility of complete change in accordance with some fundamental criterion.

By 'criterion' I mean a standard by which all political possibilities are judged. Ideologies are, in fact, different answers to the question: 'If we do not uncritically depend on traditional institutions, beliefs and practices then what is the criterion by which we should do this rather than that?' An ideology is a view about what ought to be thought, said and done about politics in terms of a sole, usually secular, criterion. And this criterion, I would argue, is best understood in terms of debt. An ideology suggests a criterion by which we act, and this criterion takes the form of an obligation - not an entitlement. To say this is, of course, to appear to restore an antique language: the language of duties rather than rights; the language of Cicero and Pufendorf. I use it here simply to capture what I think is the proper nature of an ideology. Here, then, is a preliminary definition:

An ideology is a view about what ought to be thought, said and done about politics in terms of a sole criterion, where that sole criterion is a suggestion about to what or whom a fundamental debt is owed.

In older times, the debt was owed to a god or a king, but now debts are owed elsewhere: we could even say that doubt about to what or whom debts are owed is constitutive of modern politics. (Ours is the age of ideologies.) A more complete definition of ideology therefore is: 
An ideology is a view about what ought to be thought, said and done about politics in terms of a sole criterion, where that sole criterion is a suggestion about to what or whom a fundamental debt is owed; and where this view is contested by views dependent on rival criteria within a situation which is constituted by the continual contestation of criteria.

This definition, as well as putting ideology in its historical place, enables us to explain the difference between the major and minor ideologies. Environmentalism suggests that we owe a debt to the earth. Nationalism suggests that we owe a debt to the nation. Feminism suggests that we owe a debt to women. Each is concerned with the status of a particular subject or object which may have been neglected and may deserve our commitment. But liberalism, socialism and conservatism are different. They address every subject, every self, every citizen, as if universal. They address all of us, and not because of some end outside ourselves, not because of this or that value, but because of a claim about the fundamental criterion by which all of us should act in the world. This criterion is the debt that is owed to the self. The self is difficult to characterise (Taylor, 1989), but it is this difficulty which makes the three major ideologies significant: for each of them attempts to characterise it. This is why the standard studies of ideologies are right to suggest that liberalism, conservatism and socialism form a triad of major ideologies, in relation to which all other ideologies are minor. But the order - the logical order - is not liberalism, conservatism and socialism, as they would have it, but liberalism, socialism and conservatism.

In what follows I sketch enough about each of these ideologies to demonstrate how they can be understood in terms of a series of related definitions. This could no doubt have been done in a different way, but here the method has simply been to use representative quotations by major authors from the last two centuries to indicate how the standard arguments for each ideology tend to cluster around a criterion. I do not want to argue that each of these ideologies in practice has a fixed, or ideal, content, or that each is a monolith. This is a common misunderstanding of my purpose. I do not deny that actual ideologies are complicated, but I claim nonetheless that each ideology can be distinguished from the others by its criterion and also related to the others by the very same criterion. There is an original criterion, and each subsequent criterion is a further specification of that original criterion. This enables us to explain why so many combinations of ideologies are possible. In practice we could adopt one criterion in relation to one issue, another in relation to a second issue, and yet another in relation to a third. That would be a matter of contingency. But in theory there is the fundamental fact that the ideological criterion of any liberal, socialist or conservative is on a continuum with the ideological criterion of the others. So the criterion of any of the three major ideologies can always be advanced to a more elaborate specification or retreated to a less elaborate one.

\section{Liberalism}

Liberalism is often treated as if it is a 'complex of doctrines' that cannot be simplified (Geuss, 2002). So we are told that it involves an enthusiasm for freedom, toleration, individualism and reason, on the one hand, and a disapproval of power, authority and tradition, on the other (Dunn, 1993). Or that it involves 'the idea of limited government, the maintenance of the rule of law, the avoidance of arbitrary or discretionary power, the 
sanctity of private property and freely made contracts, and the responsibility of individuals for their own fates', complicated by 'state involvement in the economy, democracy, welfare policies, and moral and cultural progress' (Ryan, 1995). All these authors agree that liberalism is not simple.

I am not alone in supposing that liberalism must have something behind all these complexities and contradictions that is simple. A century and a half ago J. H. Newman declared that the fundamental theoretical principle of liberalism is that "no one should believe what he does not understand' (Newman, 1890, p. 294).

\begin{abstract}
[Liberalism] is the mistake of subjecting to human judgements those revealed doctrines which are in their nature beyond or independent of it, and of claiming to determine on intrinsic grounds the truth and value of propositions which rest for their reception simply on the existing authority of the Divine Word (Newman, 1890, p. 288).
\end{abstract}

This is of course not a political principle in itself, although it can be found in politics. More recently, Jeremy Waldron (1987, p. 127), even while acknowledging that 'we are unlikely to find any single cluster of theoretical and practical propositions that might be regarded as the core or the essence of the ideology', has claimed that, politically, liberalism 'rests on a certain view about the justification of social arrangements'. This view is that everything has to be 'capable of being made acceptable to every last individual' (Waldron, 1987, p. 128). So, '[a] social and political order is illegitimate unless it is rooted in the consent of all those who have to live under it: the consent or agreement of these people is a condition of its being morally permissible to enforce that order against them' (Waldron, 1987, p. 140). In other words, if an ideology is the suggestion that any political order should be ordered according to the most fundamental debt owed, then the liberal claims that this debt is owed to the self. The pure thought of liberalism is that only the self has infinite credit: everything else is an instrument of that credit, and is in debt in relation to this credit.

It is necessary to say, of course, that this by itself is too simple. Some older definitions of liberalism, if taken simply, sound like definitions of anarchism. Harold Laski (1936, pp. 14-5) thought that liberalism is 'not a clear-cut body of doctrine', but he defined it nonetheless by saying the liberal seeks 'to indicate the right of the individual to shape his own destiny, regardless of any authority which might seek to limit his possibilities'. L. T. Hobhouse (1911, p. 123) was just as cautious: yet although he listed many 'elements' of liberalism, and expressed reluctance to give any of them priority, he nonetheless located the 'heart' of liberalism in the belief 'that society can safely be founded on a self-directive power of personality'. Neither Laski nor Hobhouse considered himself to be an anarchist. However, these quotations indicate that anarchism seems to be what Hegel would have called the abstract concept of liberalism.

It is certainly true that in the abstract liberalism is negative, anarchic, against law. Liberalism is the original of the major ideologies because it offers the simplest critique of what Hannah Arendt (1990, p. 117) called the 'Roman trinity' of religion, tradition and authority. It is a name for the justification for cutting the tree of an old unenlightened order at the root. Yet liberalism is not anarchism, because, as Waldron rightly emphasised, it is concerned with order. Liberalism recognises that its emphasis on the self is only a means of judging an order, but is not by itself sufficient to enable that order to exist. The 
liberal must postulate the existence of an external order. This, as we shall see, is not the case with socialism or conservatism, which, by extending the original criterion, extend it so far that it includes order. Liberalism cannot take some sort of order for granted, and so has to insist on the necessity of an order external to the self, but without which the self cannot exist. This order is law.

Perhaps the best way to express this is to say that the liberal always divides the world into three: into what is intrinsically necessary (the self), what is necessary to support that intrinsic necessity (a system of standards, rules, laws), and what is contingent (everything else, including all other beliefs, practices and institutions). Although Kant was nothing as simple as a liberal, his writings clearly state the liberal view of law. He makes it clear that an order is founded upon 'three principles, firstly, the principle of freedom for all members of a society (as man); secondly, the principle of the dependence of everyone upon a single common legislation (as subjects); and thirdly, the principle of legal equality for everyone (as citizens)' (Kant, 1991, p. 99; emphasis in original). Each self exists in relation to other selves in terms of right, where 'right is the sum total of those conditions within which the will of one person can be reconciled with the will of another in accordance with a universal law of freedom' (Kant, 1991, p. 133). All subsequent liberalism has followed this separation of selves opposed to and maintained by a structure, where the structure is right or a law established through consensus. John Rawls' (2001, p. 48) 'basic structure' is a re-statement of Kant's view without Kant's metaphysics. In liberalism the relation between one self and another is contingent, not constitutive; and it is law which enables the freedom of separate selves to co-exist. As expressed in Rawls' first principle of justice, this means that 'each person has an equal right to the most extensive equal basic liberties compatible with a similar system of liberty for all' - so that, as he puts it, 'liberty can be restricted only for the sake of liberty itself' (Rawls, 1972, p. 244).

Liberalism is the fundamental form of modern ideology because of the apparent simplicity of its criterion. The direct appeal to the self, especially the reason of that self (whether understood as rationality or reasonableness), is what made enlightenment possible. It also explains why the liberal is usually far clearer in argument than the socialist or the conservative. Of course, liberal arguments can never be decisive, for the criterion is all too easy to criticise. If the liberal argues that every obligation depends on consent, for instance, then by his own argument there is no obligation to submit to his argument since that argument makes it possible to withhold consent to it (Clark, 1989, p. 17). And of course the self can be objected to on the grounds that it is too abstract in sketching someone who has never lived and never could (Sandel, 1982). It is because the self is unstable internally (in relation to itself) and externally (in relation to society) that it has been criticised by psychologists and philosophers in one register and by socialists and conservatives in another. But the criticism amounts to the same thing: the argument that the self cannot be separated from its conditions. This is an objection which the liberal simply has to rebut. It cannot be refuted. So liberalism begins and ends with the rebuttal of any claim that the self is constituted by its conditions.

The other major ideologies have a strange relation to liberalism, never sure whether they are here to complete it or destroy it. 'There are two types of liberalism in history', comments Dunn (1993, p. 35). 'The first is rational, transcendental and concerned with 
consciousness - the one Marx came to fulfil; and the second is mechanical, reductive and concerned with desires - the one Marx came to bury.' Perhaps Hegel's term 'aufheben', or 'to sublate', is useful here in suggesting how the other ideologies at one and the same time try to retain, transform and supersede liberalism. Be that as it may, it is certainly true that the more liberal liberalism is, the more it comes to trespass on the territory claimed for socialism and conservatism. Rawls' first principle of justice is 'lexically prior' to the second principle of justice, which concerns some sort of redistribution and has made his theory of great interest to socialists (Cohen, 2009). By 'lexically prior', Rawls meant that the latter could not trump the former. This was eminently liberal, but in his last restatement of his theory of justice he admitted - albeit in a footnote - that the first principle of justice could in fact 'be preceded by a lexically prior principle requiring that basic needs be met, at least insofar as their being met is a necessary condition for citizens to understand and to be able fruitfully to exercise the basic rights and liberties' (Rawls, 2001, p. 44 n. 7). ${ }^{7}$ Rawls never made it clear whether such a need is something contingent or something constitutive. A socialist would insist that the liberal criterion has to be complicated and extended; while a liberal, in order to resist the complication that would lead to the abandonment of his own criterion, would have to fall back on a rebuttal of the sort we find in Ludwig von Mises (1972, p. 94), who declared that socialism is 'antiliberalism camouflaged as super-liberalism'. According to the liberal, whatever we want to achieve in the world can only be judged in terms of the fact that the fundamental debt is the one owed to the self.

\section{Socialism}

Socialism adjusts the criterion of liberalism in such a way that it is radically altered. If the criterion of liberalism is that debts are owed to the self, then the criterion of socialism the standard by which it judges entities, institutions and events - is that debts are owed to the self as constituted by society. This changes everything: for while liberalism opposes the self to a system or structure and then sees the rest of society as composed of selves also related to this system (and secondarily to each other), socialism takes the sociability of the self to be so fundamental that it cannot be abstracted from the self without error. As Marx puts it in the Grundrisse: 'Society does not consist of individuals; it expresses the sum of connections and relationships in which individuals find themselves' (Freeden, 1996, p. 426). This is the fundamental presupposition of socialist thought. It is what Karl Popper found objectionable when he found it in the thought of Adorno and Habermas (Popper, 1992, pp. 92-4). It is that everything must be valued or judged in relation to a self not abstracted from society, but a fully social self.

Socialism always involves a critique of liberalism. The liberal's own valuation of liberalism is rejected, and liberalism is now seen to be an ideological manifestation of a certain social order. It was not long after the French Revolution that critics of liberalism noticed that it 'combines within itself a drive towards ideals of political equality with an actual fostering of economic inequality' (MacIntyre, 1968, p. 133). Those who thought this contradiction had to be overcome were socialists. W. H. Mallock once caustically observed that capitalism is an 'actual working system' whereas socialism is 'not an alternative' but only 'a theory or belief that such an alternative is possible' (Mallock, 1908, 
p. 3). Socialists, in claiming that liberalism is an ideology about an actuality, have invariably gone on to claim that socialism is also an ideology about an actuality. And Marxists have added to this claim an absolute conviction of historical necessity.

Socialism is complicated in a way that liberalism and conservatism are not by the existence of the dominant ideological tradition of Marxism within it. There is nothing in liberalism and conservatism that even slightly resembles Marxism. I would say that this is because liberals can fall back on the apparent simplicity of the recognition of some sort of self in law and conservatives can fall back on the apparent simplicity of an already existing order. Socialists have a much more complicated task, which is to explain the significance for politics of the suggestion that the self is socially constituted. The parts of Marx's writings that have survived are his criticisms of liberalism and capitalism. His essay on The Jewish Question contrasts a liberal 'political emancipation' to a socialist 'human emancipation'. He argued that the political emancipation achieved by liberals is 'of course a great progress' but it does not resolve anything. What does liberalism achieve? 'Man is not freed from religion; he receives freedom of religion. He is not freed from property; he receives freedom of property. He is not freed from the egoism of trade; he receives freedom to trade' (Marx, 2000, p. 63). Marxism was the attempt to prove Mallock wrong: to prove that socialism was a rival order to that of liberalism - an argument which usually worked by claiming that socialism was the historical successor of liberalism.

It is important to mention history here, since it is part of my claim that the socialist criterion of a self extended to include society is not extended as far as the conservative criterion of a self extended to include not only society but history. Marxism originated in the attempt to see the failure of liberalism (and capitalism) in a historically conscious way. A Marxist is someone who attempts to understand why the shift from an unenlightened order to an enlightened order was not as successful as many had anticipated, and then attempts to understand how socialism can be the historical completion of this shift. Marx did not succeed in making full sense of it. 'For all its grandeur his achievement remained fragmentary when measured against the original plan of his work' (Lichtheim, 1968, p. 216). For as soon as Georges Sorel, Georg Lukàcs and others had recognised that historical materialism had no predictive power, the positive achievement was in ruins. Little has been done since to resolve this problem. As Perry Anderson (1976, p. 111) reminds us, 'the exact status of history within historical materialism has paradoxically never hitherto been adequately debated' by Marxists. So this is where it is possible to distinguish socialism and conservatism. Even if a socialist is conscious of history and wants to understand it, he does not suppose that we owe a debt to the traditions found in history. The conservative, as we shall see, does suppose that we owe such a debt.

Socialism has had most success in the form of critique. If anarchism is the negative moment of liberalism, then critique is the negative moment of socialism. Its greatest achievement has been its 'understanding of the intrinsic defects of a capitalist mode of production’ (Dunn, 1984, p. 37). Yet Leszek Kolakowski (1981, Vol. III, p. 530) was not alone in judging that Marxism is a religion of the 'self-deification of mankind'. A more generous analysis is that it is 'a secularised version of the Christian judgement upon, rather than the Christian adaptation to, the secular present' (MacIntyre, 1968, p. 143). Certainly, the intensification of the criterion in socialism has meant it has always required much more 
in the way of research than has ever been required by liberalism, which can, at its simplest, appeal to the selfishness of the self - and otherwise, fall back on argument. Socialism has always depended far more on hope in the future than either liberalism or conservatism. Babeuf, St Simon, Fourier, Proudhon, even Marx, thought that men could and would live in a state of equality and mutual love. The full and free development of every individual in socialism is, as Agnes Heller and Ferenc Fehér (1991, p. 198) put it, 'the freedom of liberalism realized in full and for everyone', but it requires the transformation of liberalism into something else.

If, as has often happened, confidence in this transformation is lost, then socialism tends to fall back into some sort of complicated or confused liberalism or illiberalism - as indicated, say, theoretically by the writings of Habermas or practically by the history of Fabianism. A century ago George Bernard Shaw wrote that socialism has a 'twofold task': one is to keep capitalism 'up to the mark by legislation', and the other is to 'get rid of it altogether by constructive substitution of socialism' (Shaw, 1996, p. 462). But these tasks are clearly completely contradictory. They are only compatible if the right hand does not know what the left hand is doing.

Socialism remains as significant as ever as a fundamental ideological possibility (Dunn, 1984). Yet the more abstract or argumentative socialism becomes the more it tends to liberalism, and the more actual or historical it becomes the more it tends to conservatism. This is because its criterion, under criticism, may seem to require retreat back to the self, or advance onto history. Socialists usually remain socialist despite these dangers by concentrating on what is wrong with the world, which is usually either an economic or an existential wrong: poverty or alienation. Even if socialists acknowledge 'the openness and indeterminacy of the social', they cannot abandon the category of 'the social' without ceasing to be socialist (Laclau and Mouffe, 1985, pp. 144-5; compare Wood, 1997). To be a socialist is necessarily to go beyond the legality of liberalism. In liberalism 'men [are] given their individuality as unique in each case, different to all others, so that it might all the more surely be made the same as every other' (Adorno and Horkheimer, 1997, p. 13). But in socialism, however it is constructed and whatever its arguments, there is a more liberal criterion than this. Socialism recognises that we are not mere selves, but selves in a situation, in a society - and that it is to these selves that a debt is owed. The self is no longer a merely selfish self, but a self constituted by its existence in society.

\section{Conservatism}

Conservatism extends the criterion even further. While liberalism offers the self - whatever that is - as a criterion of judgement, and while socialism offers an extension of this criterion so it includes the social - whatever that is - as a criterion of judgement, conservatism supposes that both of these are too abstract. As we have seen, the socialist agrees with this to some extent, but remains committed to the idea of fulfilling what he considers the historical task of liberalism. The conservative goes further and says that the criterion of a self constituted by both social and historical existence means that there is no historical task - only the necessity of not sundering ourselves from history, as liberals and even socialists seem to require us to do. We have a debt to those who are dead as well as to those who are alive. 
As Edmund Burke (1999, p. 193) put it, we have to see ourselves as involved in 'a partnership not only between those who are living, but between those who are living, those are dead, and those who are to be born'. What does this mean? In its simplest or most abstract form, the conservative is inclined to hold onto what he has rather than seek what he does not have. Michael Oakeshott (1991, p. 408) said that conservatism, understood as a 'disposition', is 'to prefer the familiar to the unknown, the actual to the possible, the limited to the unbounded, the near to the distant, the convenient to the perfect'. Conservatives argue that there is no obligation to change the world because human imperfection, on the one hand, and unforeseen consequences, on the other, make it impossible to know that any change will be for the better (Stove, 2003). If we do change anything, it should be in terms of the considered judgements of the past, for the reason that we cannot depend on our own experience. "We ought to be wary of dismissing doctrines merely because we can ourselves see little or no reason to believe them, even if we hardly understand them' (Clark, 1989, p. 17). So, as Hans-Georg Gadamer (1989) argued, we need our prejudices and the traditions which are the embodiment of those prejudices.

As many have observed, resistance to change is the abstract concept or negative moment of conservatism. Yet in politics, as elsewhere, conservatives have always had to accept the necessity of change. Conservatism is 'concessionary'. Ever since Robert Peel, it has involved the view 'that the highest virtue in politics is to resist change until change becomes inevitable, and then to concede to it with as little fuss and as much obeisance to tradition as possible' (Utley, 1989, p. 87). Or, to put it another way, conservatism is 'compatible with all manner of change, provided only that change is also continuity' (Scruton, 1984, p. 11). Conservatism can therefore be forced to conserve in a later generation what it would not have conserved in an earlier one.

This brings us to the contradiction of conservatism. Conservatism is rarely abstract, merely reactive or inertial (Alexander, 2013). Usually it has something behind it, some ideal that is not simply holding on to what one has. This ideal is not an abstract value, or an expectation of deliverance from history or in history. Conservatives look backwards, not forwards, and so look to the very traditions which liberalism and socialists put into question. This is why they are less securely secular than liberals or socialists. Even if a conservative is not religious, he tends to respect religion. Unlike the liberal or the socialist, who attempts to liberate man from tradition, the conservative seeks no liberation from tradition. He has a criterion which is an extension of the original criterion, but which is extended so far that it appears to require the restoration of a traditional order, even religious order, which, according to the criterion, cannot be restored. Or, to put it another way, the conservative has to accept the existence of an order that emerged from a revolution he could never have sanctioned at the time.

Conservatism expects far less of the future or even the present than does liberalism or socialism because even when it is not religious, it locates eschatology in, and only in, religion. W. R. Inge wrote that 'secularism like other religions, needs an eschatology' (Inge, 1919, p. 26; compare Anderson, 1976, p. 109). Conservatives often claim that liberals and socialists, in having an eschatology, also have a religion: a claim which liberals and socialists, given their assumptions, are under no obligation to admit. This, 
by Evelyn Waugh (1939), is a typical conservative utterance in its appearing to depend on a religious point of view:

I believe that man is by nature an exile and will never be self-sufficient or complete on this earth; that his chances of happiness and virtue, here, remain more or less constant through the centuries, and, generally speaking, are not much affected by the political and economic conditions in which he lives.

Waugh thought that 'men cannot live together without rules' but that 'there is no form of government ordained from God as being better than any other'. Against socialism, he maintained 'that inequalities of wealth and position are inevitable and that it is therefore meaningless to discuss the advantages of their elimination (Waugh, 1939, pp. 16-7). The conservative tends to see liberalism and socialism as Nietzsche saw them, philosophically as relics of Christianity, and historically as episodes in the decline of Christianity (Nietzsche, 1968, pp. 401 and 411). But, unlike Nietzsche, the conservative insists, as Joseph de Maistre (1994, p. 41) put it, that 'institutions are strong and durable to the degree that they are, so to speak, deified'. What 'deified' means is of course a question the conservative without religion sometimes finds it difficult to answer.

The oddity of conservatism has to be emphasised. Conservatism accepts the enlightened view that we need a criterion but extends the criterion so far that instead of offering an almost total transformation it offers an almost total restoration. It agrees with socialism that emancipation should not only be that of an abstract individual, but it lays such emphasis on the debt to the past that it makes any sort of utopian or scientific socialism impossible. This is a great problem for the conservative. 'A few years ago,' wrote Burke (1999, pp. 112-3), 'I should be ashamed to overload a matter, so capable of supporting itself, by the then unnecessary support of any argument.' The conservative in general distrusts argument, because argument simplifies what should not be simplified. This is why conservative argument usually takes the form of negation, or reaction. Against the positive assertions of liberals and socialists the conservative issues rebuttals, and otherwise defends what he can in silence. Yet in rational terms conservatism is the enlightened form of the discovery that enlightenment is an error that leaves the world 'stripped of every relation, in all the nakedness and solitude of metaphysical abstraction' (Burke, 1999, p. 93). Its criterion is the complete, even if contradictory, one, that we owe a debt to the self as constituted by its existence not only in society, but also in history.

\section{Conclusion}

So far the scholars of ideologies have collected specific concepts under a common generic idea of ideology. This article has been an exercise not in collection but in division, in order to put forward a hierarchical arrangement by which the relation of these three major ideologies to each other may be understood.

An ideology is a view about what ought to be thought, said and done about politics in terms of a sole criterion. Since no one before the era of enlightenment thought that a sole criterion could be used as the standard of political judgement it is important to emphasise the fact that ideologies are a modern idea - even if we now are able discover other 'ideologies' in older times. An ideology, in short, is a view about judging politics in terms 
of to what or whom a fundamental debt is owed. The three major ideologies suppose that the debt is owed to the self. Since each ideology characterises the self in a different way, we are able both to distinguish them and identify the continuity between them. The three ideologies form a triad of successive elaborations of an original criterion. Liberalism is the simple assertion of this original criterion, socialism is the assertion of a more complicated version and conservatism the assertion of an even more complicated version of it. Perhaps I should say that there is nothing philosophically necessary about the terms 'liberalism', 'socialism' and 'conservatism'. As used in British English, they are of course historically contingent, but I think they express real distinctions in modern political thought. If I were writing pure political philosophy I could perhaps find more elegant words for them; but this would be to ignore the achievements of our political tradition and the fact that my theory is supposed to be a recapitulation at a theoretical level of one element of that tradition.

Each ideology is enlightened and critical. Each takes order seriously. And each is critical of a particular order in relation to which it posits itself as having a superior criterion. ${ }^{8}$ To use the phrase made famous by Theodor Adorno and Max Horkheimer (1997), they form a dialectic of enlightenment. The old, unenlightened order is without a criterion, or with one which is sacred and arcane - hence traditional, not critical. Liberalism is a criticism of that older order. Socialism is a criticism of any liberal order as well as of the older order criticised by liberalism. And conservatism is a criticism of any socialist order as well as of any liberal order. So there is a circle. Each ideology subjects the logically prior ideology or ideologies to the criticism that its criterion is incomplete. ${ }^{9}$

Let me illustrate the circularity briefly in relation to three important issues: namely, emancipation, equality and religion. First, emancipation. Liberalism is an emancipation from the unenlightened liberties justified by tradition to an individual liberty, which is legal or political, justified by the secular criterion of the self. Socialism is this emancipation completed, so it is also an emancipation from individual liberty. And conservatism is an emancipation from even this, so that liberty is not in terms of the completion of this emancipation, but in terms of the recognition of the incomplete nature of any abstract or unhistorical liberty. Second, equality. Liberalism is wholly for equality, but only an equality of the self in relation to all other selves in terms of a shared structure of law. Socialism seeks an equality that does not offer the same to every self, but offers the same to every self as constituted socially. This creates a difficulty about whether socialism is about equality as such, or instead some sort of overcoming of inequalities according to phrases like: 'From each according to his abilities, to each according to his needs.' And if there is any enthusiasm for equality in conservatism at all, as more than a concession to secularity, it is in the sense that we are all equal before God. This equality is so fundamental that it makes all other possible forms of equality, liberal or socialist, irrelevant. Clearly, it is not a very extensive liberty in itself, in this world. Third, religion. Liberalism separates 'church' and 'state' by locating all matters of religion in privacy, so leaving the secular state dominant in public. Socialism alleges that the separation is an error, which leaves the self in thrall to religion: so it refuses the separation and instead suggests that church and state together have to be transformed. This 
throws up two formal possibilities. It could involve the secularisation of religion, so that religion is emptied of its mythical, metaphysical or transcendental content and restored to humanity not merely as a 'religion of humanity', but as a praxis. Or it could involve a secular interpretation of certain precepts of religion. And conservatism alleges that both are errors, since religion is what it is, in its publicity and its authority: so it should neither be displaced nor replaced. It should suffer no form of secularisation, but remain authoritative (or as authoritative as it happens to be in our time).

This ordering of ideologies indicates why liberalism tends to issue in legislative changes, why socialism tends to issue in distrust of merely legislative changes, seeking something more radical or even revolutionary, and why conservatism tends to issue in distrust of both legislative and radical changes. It explains why liberals are concerned with law, why socialists are concerned with economy, society and power, and why conservatives are concerned with tradition and the religion manifest in tradition.

The picture sketched here of the major ideologies as both related and distinct is one that can prevent the study of ideologies from falling into the irrelevance of endless collection. Division is necessary to prevent the subject floating away in Gangetic tides. The fact that for two centuries we have spoken of 'liberalism', 'socialism' and 'conservatism' means that there are simplicities here: something continuous in each ideology that enables us to believe that we are speaking about the same things that were first spoken of in the early nineteenth century. All sorts of confusions and compromises are of course possible in any given ideology, but, if I am right, there is order in the three ideologies. At root, liberalism is the minimum specification of an enlightened politics, socialism is an intensified specification of an enlightened politics and, odd as it may sound, conservatism is the maximum specification of an enlightened politics - which, ironically, gestures towards the restoration of an unenlightened politics. The consequence of this circularity is that we may consider all ideologists to be dialecticians of enlightenment writing at different stages of the dialectic. This theory should enable us to do what is so rarely done in modern academic writing, which is to explain the relation between political philosophy written in different ideological registers. In other words, there is a relation between Rawls' theory of justice, Rancière's dissensus and Cowling's 'Jacobitism of the mind'.

There are many ways to characterise the three major ideologies, but Marx's from the Grundrisse is not a bad one, so I end with a set of variations upon it.

Society consists of individuals.

Society does not consist of individuals; it expresses the sum of connections and relationships in which individuals find themselves.

Society does not consist of individuals; it does not even express the sum of connections and relationships in which individuals find themselves: it is the expression of the connections and relationships which emerged from a past that is no longer present and have to be conveyed to a future that is not yet present.

(Accepted: 12 December 2013) 


\section{About the Author}

James Alexander is an Assistant Professor in the Department of Political Science at Bilkent University, Ankara, Turkey. He is the author of 'The Four Points of the Compass', (Philosophy, 87 (1), 2012, pp. 79-107), 'Oakeshott as Philosopher', in The Cambridge Companion to Michael Oakeshott (Cambridge, 2012), 'The Contradictions of Conservatism' (Government and Opposition, 48 (4), 2013, pp. 594-615), 'Notes Towards a Definition of Politics' (Philosophy, forthcoming, 2014) and 'The History of Political Philosophy', in The Bloomsbury Companion to Political Philosophy (Bloomsbury, 2014). James Alexander, Department of Political Science, Bilkent University, Ankara 06800, Turkey; email: jalexand@bilkent.edu.tr

\section{Notes}

I would like to acknowledge the comments and criticism of Julinda Abdi Hoxha, Gulbanu Altunok, Sengul Apari, Michael Freeden, Ben Holland, Banu Helvacioglu, Paul Latimer, Cadoc Leighton, Elisabeth Ozdalga, Andrew Vincent and the reviewers of the Journal of Political Ideologies, the Journal of Politics and, of course, Political Studies.

1 There is not space to consider the recent Oxford Handbook of Political Ideologies, where even more definitions of 'ideology' are collected, and where there are as many definitions of 'ideology' as there are chapters. It seems to be standard nowadays to quote Nietzsche's claim that whatever has a history cannot be defined as if it is uncontroversial and incontrovertible (Freeden et al., 2013 , p. 3.) In this article, for obvious reasons, I have to begin somewhere, and so I start with what I call the standard definition rather than the fact that scholars now openly doubt that definition is possible while nonetheless putting forward definitions of their own.

2 For versions of the definition, see Heywood (1998, p. 12); Vincent (1992, p. 16); Freeden (1996, p. 75). Heywood's and Vincent's books have served as textbooks since 1992, running to four and three editions, respectively, while Freeden's monograph is still, as far as I know, the only attempt to theorise ideology in English. He has recently restated his position without altering it, changing the order to the one adopted in the present article (liberalism, socialism, conservatism) without explanation. See Freeden (2003, pp. 81-93). See also his chapter in Freeden et al. (2013). The standard definition is also evident in Festenstein and Kenny (2005).

3 Freeden insists on p. 553 that we can write about ideology in terms of a 'few main categories', but does not explain why.

4 Heywood's Political Ideologies has chapters on Liberalism, Conservatism, Socialism, Nationalism, Anarchism, Fascism, Feminism and Fundamentalism. Vincent's Modern Political Ideologies has chapters on Liberalism, Conservatism, Socialism, Anarchism, Fascism, Feminism and Ecologism. Freeden's Ideologies and Political Theory has chapters on Liberalism, Conservatism, Socialism, Feminism and Green Political Theory. Compare also Festenstein and Kenny, Political Ideologies, which has chapters on Liberalism, Conservatism, Socialism, Nationalism, Feminism, Ecologism, Anarchism and Fascism.

5 For liberalism as the 'dominant ideology', see Heywood (1998, p. 26) and Freeden (1996, passim). For the 'most complex and intricate' ideology, see Vincent (1992, p. 22). For 'major ideologies', see Heywood (1998, p. 21); and for 'major ideological families', see Freeden (1996, p. 139).

6 For Freeden's characterisations of each ideology, see Freeden (1996, pp. 178, 340 and 425-6).

7 See also pp. 176-9 for Rawls' anxious attempt to rebut Marx's 'critique of liberalism'. He nowhere considered that there could be a conservative principle that states, say, 'that all expectation of need or right or liberty be subjugated to revelation as interpreted by authority in institutions and maintained through appropriate traditions' - another lexically prior principle that would cause chaos in all the lexically anterior principles.

8 Since Marx's time ideologies have been understood to represent interests (Freeden, 1996, p. 106), there is always value in dismissing ideologies, or other ideologies, as 'ideological' (Vincent, 1992, p. 13). Heywood (1998, p. 15) sketches an interesting pattern of the way ideologies are dismissed as 'ideological' by other ideologies, but unfortunately he does not observe that some sort of logic - of the sort sketched in this article - is intimated in this pattern.

9 This is of course not to say that criticism of any ideology by any other ideology is not possible. See, for instance, Mises (1972), which is a criticism of socialism in terms of liberalism, or Anderson (2005), which is a criticism of conservatism in terms of socialism.

\section{References}

Adorno, T. and Horkheimer, M. (1997) Dialectic of Enlightenment. Trans. J. Cumming. London: Verso.

Alexander, J. (2013) 'The Contradictions of Conservatism', Government and Opposition, 48, 594-616.

Anderson, P. (1976) Considerations on Western Marxism. London: New Left Books.

Anderson, P. (2005) Spectrum. London: Verso.

Arendt, H. (1990) On Revolution. London: Penguin.

Burke, E. (1999) Reflections on the Revolution in France. Indianapolis, IN: Liberty Fund.

Clark, S. R. L. (1989) 'Reason, Value, Tradition', in S. R. L. Clark, Civil Peace and Sacred Order: Limits and Renewals, Vol. I. Oxford: Clarendon Press, pp. 1-26.

Cohen, G. A. (2008) Rescuing Justice and Equality. Cambridge, MA: Harvard University Press.

Cohen, G. A. (2009) Why Not Socialism? Princeton, NJ: Princeton University Press.

Dunn, J. (1984) The Politics of Socialism. Cambridge: Cambridge University Press.

Dunn, J. (1993) 'Liberalism', in J. Dunn, Western Political Theory in the Face of the Future, $2^{\text {nd }}$ edn. Cambridge: Cambridge University Press, pp. 29-56. 
Festenstein, M. and Kenny, M. (eds) (2005) Political Ideologies: A Reader and Guide. Oxford: Oxford University Press. Freeden, M. (1996) Ideologies and Political Theory: A Conceptual Approach. Oxford: Clarendon Press.

Freeden, M. (2003) Ideology: A Very Short Introduction. Oxford: Oxford University Press.

Freeden, M., Sargent, L. T. and Stears, M. (eds) (2013) The Oxford Handbook of Political Ideologies. Oxford: Oxford University Press.

Gadamer, H.-G. (1989) Truth and Method. New York: Continuum.

Geuss, R. (2002) 'Liberalism', in R. Geuss, History and Illusion in Politics. Cambridge: Cambridge University Press, pp. 69-109.

Heller, A. and Fehér, F. (1991) The Grandeur and Twilight of Radical Universalism. London: Transaction.

Heywood, A. (1998) Political Ideologies: An Introduction, $2^{\text {nd }}$ edn. London: Macmillan.

Hobhouse, L. T. (1911) Liberalism. London: Williams \& Norgate.

Inge, W. R. (1919) Outspoken Essays. London: Longmans, Green.

Kant, I. (1991) Political Writings, $2^{\text {nd }}$ edn. Trans. H. B. Nisbet. Cambridge: Cambridge University Press.

Knight, K. (2006) 'Transformations of the Concept of Ideology in the Twentieth Century', American Political Science Review, 100, 619-26.

Kolakowski, L. (1981) Main Currents of Marxism. Trans. P. S. Falla. Oxford: Oxford University Press.

Laclau, E. and Mouffe, C. (1985) Hegemony and Socialist Strategy: Towards a Radical Democratic Politics. London: Verso.

Laski, H. J. (1936) The Rise of European Liberalism: An Essay in Interpretation. London: George Allen \& Unwin.

Lichtheim, G. (1968) The Origins of Socialism. London: Weidenfeld \& Nicolson.

MacIntyre, A. (1968) Marxism and Christianity. Note Dame, IN: University of Notre Dame Press.

Maistre, J. de (1994) Considerations on France. Trans. R. Lebrun. Cambridge: Cambridge University Press.

Mallock, W. H. (1908) A Critical Examination of Socialism. London: John Murray.

Marx, K. (2000) 'On the Jewish Question', in K. Marx, Selected Writings, $2^{\text {nd }}$ edn. Ed. D. McLellan. Oxford: Oxford University Press, pp. 46-64.

Mises, L. (1972) The Anti-Capitalistic Mentality. South Holland, IL: Libertarian Press.

Newman, J. H. (1890) Apologia Pro Vita Sua, Being a History of His Religious Opinions. London: Longmans, Green.

Nietzsche, F. (1968) The Will to Power. Trans. W. Kaufman. New York: Vintage Books.

Oakeshott, M. (1991) 'On Being Conservative', in M. Oakeshott, Rationalism in Politics and Other Essays. Indianapolis, IN: Liberty Fund, pp. 407-37.

Popper, K. (1992) In Search of a Better World: Lectures and Essays from Thirty Years. London: Routledge.

Raven, J.E. (1965) Plato's Thought in the Making: A Study of the Development of his Metaphysics. Cambridge: Cambridge University Press.

Rawls, J. (1972) A Theory of Justice. Oxford: Oxford University Press.

Rawls, J. (2001) Justice as Fairness: A Restatement. Ed. E. Kelly. Cambridge, MA: Belknap Press.

Ryan, A. (1995) 'Liberalism', in R. Goodin and P. Pettit (eds), A Companion to Contemporary Political Philosophy. Oxford: Blackwell, pp. 291-311.

Sandel, M. (1982) Liberalism and the Limits of Justice. Cambridge: Cambridge University Press.

Schwarzmantel, J. (1998) The Age of Ideology: Political Ideologies from the American Revolution to Postmodern Times. London: Methuen.

Scruton, R. (1984) The Meaning of Conservatism, $2^{\text {nd }}$ edn. London: Macmillan.

Seliger, M. (1976) Ideology and Politics. London: Allen \& Unwin.

Shaw, G. B. (1996) 'Socialism and the Living Wage: Labour's Twofold Task', in B. Tyson (ed.), Bernard Shaw's Book Reviews, 1884 to 1950. Vol. 2. London: Pennsylvania State University Press, pp. 462-5.

Stove, D. (2003) 'Why You Should Be Conservative', in D. Stove, On Enlightenment. London: Transaction, pp. 171-8.

Taylor, C. (1989) The Sources of the Self: The Making of the Modern Identity. Cambridge: Cambridge University Press.

Utley, T. E. (1989) A Tory Seer: The Selected Journalism of T. E. Utley. Eds C. Moore and S. Heffer. London: Hamish Hamilton.

Vincent, A. (1992) Modern Political Ideologies. Oxford: Blackwell.

Vincent, A. (2004) The Nature of Political Theory. Oxford: Oxford University Press.

Waldron, J. (1987) 'Theoretical Foundations of Liberalism', Philosophical Quarterly, 37, 127-50.

Waugh, E. (1939) Robbery under Law. London: Chapman \& Hall.

Wood, E. M. (1997) The Retreat from Class: A New 'True' Socialism, $2^{\text {nd }}$ edn. London: Verso. 